\title{
Analyzing the impact of the functions of Project Management Offices on triple constraints performance of new product projects
}

\author{
Sanderson César Macêdo Barbalho", Vaniele Guimarães de Carvalhob, Gladston Luiz da Silvac, José Carlos de Toledod \\ aDepartamento de Engenharia de Produção, Faculdade de Tecnologia, Universidade de Brasilia - UnB \\ 'Programa de Pós-graduação em Sistemas Mecatrônicos, Faculdade de Tecnologia, Universidade de Brasilia - UnB \\ 'Departamento de Estatística, Instituto de Ciências Exatas, Universidade de Braślia - UnB \\ dDepartamento de Engenharia de Produção, Universidade Federal de São Carlos - UFSCar \\ e-mails: sandersoncesar@unb.br; vanieleguimaraes@gmail.com; gladston@unb.br; toledo@dep.ufscar.br
}

\begin{abstract}
Aiming to understand the relationships between the functions of project management offices (PMO) and the performance of new product development projects, this paper presents correlations between the effort in performing PMO functions and the results of performance indicators on a sample of 35 companies that develop new products and have PMOs in their organizational structure to support it. It was analysed these functions from the point of view of performance indicators related to project's triple constraints. The data was analysed using Spearman correlation. In general, it was observed that PMOs are not focused on activities as providing project success on time, cost or scope. Schedule performance is correlated to functions of reporting project status to senior managers. Cost performance is correlated to benefit management. No function presented any correlation with preventing scope changes. These results point that the presence of PMO on the companies' structure does not guarantee the success on project's triple constraints maybe because it is focused on organizational project management and not in performing project management as well.
\end{abstract}

Keywords: Project Management Offices, new products development, project performance, triple constraint, PMO functions.

\section{Introduction}

Project Management Office (PMO) is a structure that provides important support to project managers, especially in the provision of management methodologies and multi-project management. Some studies (DAI; WELLS, 2004; JULIAN, 2008) show that the awareness of performance on cost, time and quality of projects managed in organizations that have PMOs is better than in structures without such organizations. In addition, researches have shown that PMOs are not static structures, or with a fixed set of functions independent of the organization where they work. Instead, PMOs are strongly determined by the company's business and by the project performance objectives (AUBRY et al., 2010).

Despite the current state of deceleration of the Brazilian economy due to political problems, the current global context is dynamic, and a strong demand in technology and engineering projects as well as development of new products have occurred. So studying the adoption of PMOs in companies that execute projects of new products can bring a set of scientific and practical contributions to the topic of product development management.

In order to advance the understanding of how Project Management Offices are structured in companies that develop new products and their implications for project performance and NPD (New Product Development), one survey was conducted on a sample of companies that develop new products, and which have Project Management Office structures to provide support for them.

So, this paper analyzes the relationship between the functions performed by project management offices and the performance of new product development projects, focusing on the roles played by the PMOs surveyed and its relation with the indicators of schedule, cost and scope, the called triple constraint or iron triangle of project performance.

It is showed below the main theoretical frameworks used. Later, it discusses the research methodology and after presents the collected data. Finally, a discussion addresses the main reflections about data presented. In the 
end, theoretical and practical considerations of the research and perspectives to its further development are described.

\section{Project management offices in new product development}

Ulrich and Eppinger (2008) argue that product development process is operated through different projects. In addition, the life cycle of a product involves a large set of projects cycles: project to make specifications for the product, to design it technically, to certify it in regulatory agencies, to release it, to remove it from the market etc. Each of these project cycles is different from the other and needs to be planned in an unique mode, according to $\mathrm{PMBOK}^{\circledR}$ Guide (PROJECT..., 2013).

The pioneering study and still today main reference in the analysis of new product development (NPD) performance is the work of Clark and Fujimoto (1991). They analyzed the automotive industry of the 80 s. It was the first major study of product development focusing on performance indicators. The authors treat the performance of the product development as a reflection of the long-term capabilities of the company and establish the total quality of the product, the development lead-time and the productivity as the NPD key performance criteria. They also state project management offices as a liaison organization about different company areas.

Some studies tried to identify critical success factors for NPD that would affect some product success metrics. Some studies about new product performance focus on factors related to leadership, strategy, organization and planning practices (COOPER; KLEINSCHMIDT, 1995; GRIFFIN; PAGE, 1996; KAHN; BARCZAK; MOSS, 2006; PALADINO, 2007) while other studies are focused on activities that generate higher performance (ROBERTS; BELOTTI, 2002; TOLEDO et al., 2008; JUGEND; SILVA, 2010; MENDES; TOLEDO, 2012).

Success is a theme that should be better understood, as there is the product success, defined by financial performance, customer value, company's sales percentage of products launched in recent years, time to investment return, market share and product quality (COOPER; KLEINSCHMIDT, 1995; GRIFFIN; PAGE, 1996; KAHN; BARCZAK; MOSS, 2006; CHIESA; FRATTINI, 2007); there is also the project success, related to the stakeholders perception of success, impact for the customer and for the team and the company's preparation for the future (MARIOKA; CARVALHO, 2014; JORDÃO et al., 2015); and there is still the success of the management of development projects, concerning especially indicators of cost, scope and project quality, particularly comparing what was planned and what was executed (MARIOKA; CARVALHO, 2014; JORDÃO et al., 2015; PATAH; CARVALHO, 2016).
In the studies of Toledo et al. (2007, 2008), Jugend and Silva (2010) and Mendes and Toledo (2012) there are surveys with companies of auto parts, industrial automation and medical equipment in order to identify the performance drivers in NPD. The results indicate the importance of the requirements planning and the management skills of project managers as key elements involved in successful projects. The authors also found that there are success factors related to the fact of technical performance of products being superior than competing products, what confirm previous international research in the area (COOPER; KLEINSCHMIDT, 1995; GRIFFIN; PAGE, 1996); and also a new driver represented by the documentation of technical details of products. Medical equipment companies rely on a good interpretation of customer needs and creativity in engineering solutions. The authors also identify that approval activities are linked to the product's success in the studied companies.

Project Management Office (PMO) is characterized as an established organizational structure to facilitate the activities of project management and bring improvements to the organization's management process through portfolio management and project alignment with corporate strategy (CRAWFORD, 2002).

Dai and Wells (2004) compared project management (PM) practices in companies with and without PMO. The authors identified more effective PM practices in companies with $\mathrm{PMO}$, especially in the registration of learned lessons and in the application of PM methodologies and techniques.

Hobbs and Aubry (2007) conducted an extensive analytical study on the PMOs activities. The presence and degree of importance of 27 different functions and roles of the PMOs were analyzed. These functions and roles were grouped based on factor analysis generating the following groups:

- Monitoring and controlling activities of project performance;

- Development of skills and project management methodologies;

- Multi-project management;

- Strategic management; and

- Organizational learning.

The authors also identified other activities considered important involving Execution of specialized tasks for the project managers and Recruiting, selection, evaluation and determining salaries of project managers. These function weren't grouped because of conceptual consistency.

For the authors, Hobbs and Aubry (2007), activities of monitoring and controlling projects performance are the 
most important within the PMO. These results were used to compose the list of functions submitted for respondents in the survey presented in this paper.

The PMOs functions identified in Hobbs and Aubry (2007) were complemented by functions identified in other studies of the literature, such as Pellegrinelli and Garagna (2009) and Barbalho et al. (2014). These functions were submitted to managers and those responsible for Brazilian PMOs that belongs to new product development, organized on a survey with non-statistical sample, as is presented on the next session.

Recent studies identify a positive relation among PMO functions and project performance. Spelta and Albertin (2012) states indeed of previous research that argue PMOs main contributions are related to time, cost and quality results of projects. Their research identify portfolio control as the main driver of PMO adoption. Ünger, Gemünden and Aubry (2012) found PMOs' controlling functions as explanation of the quality of project portfolio management. Spalek (2013) states in a research with 259 PMOs a difficulty in demonstrating the added value of them, but argue that when the company successfully operate its Project Management Office, they positively influence industrial engineering performance specially in long-term planning, multi-project environment, and according the maturity of the company's PMO.

Some studies of Brazilian researchers focus on projects of development of new products under a prism of project management practices. Jucá Junior et al. (2010) studied software developer companies under the focus of CMMI (Capability Maturity Model Integration) and found that this standard is not appropriate to analyze NPD practices in small businesses. Silva et al. (2010) discusses the application of risk management techniques in companies that products parts of cars. Conforto et al. (2014) discusses practices of agile project management in innovative projects.

Toledo et al. (2007) survey a number of small Brazilian high technology firms trying to understand what their drivers for new product success are. The results comply with international researches when identify the importance of a strong and detailed up-front homework and management skills associated with team-based design as drivers, but the authors identify that the activity of "providing project documentation" is a driver too. Silva et al. (2007) presents a complementary work in which technology firms from medical and industrial automation are compared. Automation companies present success projects strongly related to superior technical performance against competitors, and medical companies rely on interpretation of consumer needs and generation of product ideas. Moreover, the authors identify that the homologation activities are well related to product success, a novelty in this kind of study when comparing to international literature.
Few analyzed studies approach PMO linked to new product development projects. Barbalho et al. (2009) discusses PMO structuration to facilitate the execution of large projects in small companies. Rabechini Junior et al. (2011) analyze the NPD of an auto parts company in which PM practices potentiated by PMO were motivated by the need of combating the lack of projects technical memory. Barbalho et al. (2014) address the different functions that PMO can take on new product development projects with very specific activities for this kind of project. Barbalho and Toledo (2014) analyze the transitions in a PMO of products development of a technology-based company, featuring the changes in terms of functions performed by the PMO. Jugend, Barbalho and Silva (2015) address the contributions that PMO can provide to the portfolio management of NPD.

These studies demonstrate that project management practices and more specifically, PMO functions and management, are relevant research topics in new product development literature, because of the imperative of innovation and the dissemination of project offices as support organizations. Moreover, no study was identified relating PMO functions and triple constraint.

\section{Methodology}

The research method adopted during this effort was an exploratory and quantitative survey with descriptive analysis aiming to withdraw conclusions by the survey diagnostic about the main functions performed by PMOs and its impact on development of new products. According Garcia (1995) a descriptive analysis of the data must be performed in order to understand the variables and build hypotheses for the use of more sophisticated statistical techniques. In this study it was considered the references of Bussab and Morettin (2003) and Heiberger and Holland (2004) to plan data analysis.

Initially the survey was based on companies that develop new products in the state of São Paulo, but it has been extended to other locations through divulgation on social networks. The first version of the questionnaire was personally applied by the researcher in three companies in order to validate and refine the questionnaire used. After this initial step, the questionnaire was consolidated and made available by Internet where companies could access and answer it. Thirty five companies that develop new products in different sectors such as automotive, automation, equipment and capital goods, consumer goods and toiletries gave validated responses to the form. Since it was applied through Google Docs and disseminated via social networks (facebook, twitter, LinkedIn and Yahoo Groups), there were respondents from various Brazilian states: São Paulo, Paraná, Pernambuco and Federal District. From the responses it was possible to make statistical analysis and calculate the correlation factors between PMO structure and 
management relating with practices of product development process operated by the company and its NPD performance in cost, schedule and scope.

\section{Results}

The surveyed companies come from many industries, ranging from energy companies and information technology companies, through automotive companies to capital goods industries.

The studied companies can be characterized by the structure of its product development, being 19 of Matrix kind of organization, nine of functional type and seven of pure project. A simple calculation shows that although 23\% of the surveyed companies have over 1000 employees.

The average number of people allocated in the surveyed PMOs was eight employees. Additionally, most of the analyzed PMOs were created in the last five years, when the concept of PMOs became widely discussed, as in academic events as in project management conferences in Brazil.

From the point of view of the tasks performed by PMOs, respondents should indicate in Likert scale, from one to five, the degree of PMO effort for each statement. There were 31 functions of the PMO analyzed in this work, identified in Hobbs and Aubry (2007) study and in other studies of the literature, according already discussed. The functions analyzed in this work can be separated on three groups: Support to the Higher Hierarchical Levels; Support to Project Managers and their teams; and Projects, Programs and Portfolios Management. Each function was represented by a variable to be easier analyzed by respondents.

The eight functions identified as Support to the Higher Hierarchical Levels are: (X1) - Report project status to senior management, (X2) - Provide coaching to senior management, (X3) - Participate in strategic planning, (X4) - Benefits management, (X5) - Recruitment, selection, evaluation and remuneration determination for PMs, (X6) - Networking and environmental monitoring, (X7) - Participation in multidepartment's committees, and (X8) - Promote project management inside the company.

The twelve functions identified as Support to Project Managers and their teams are: (X9) - Develop and implement a standardized methodology, (X10) - Develop Project Management skills, including training, (X11) - Implement and operate the information system on projects, (X12) - Monitor and control the PMO performance, (X13) - Provide tools without any specific effort to standardize it, (X14) - Implement and manage the lessons learned database, (X15) - Implement and manage the risk database, (X16) Provide coaching for project managers, (X17) - Management of engineering changes, (X18) - Perform specialized activities for project managers (Ex. Preparation of schedules, etc), (X19) - Management of manufacturing items for prototypes/deliveries, and (X20) - Management of purchasing items for prototype /deliveries.

Eventually, the eleven functions identified as Projects, Programs and Portfolios Management are: (X21) - Provide proactive ways for organizational learning between projects, (X22) - Monitor and control project performance, (X23) - Coordination between projects, (X24) - Develop and maintain a scoreboard of projects, (X25) - Manage one or more portfolios, (X26) - Identify, select and prioritize new projects, (X27) - Manage files of project documentation, (X28) - Manage one or more programs, (X29) - Conduct project audits, (X30) - Set resources allocation among projects, and (X31) - Conduct evaluation of project to its end.

In the questionnaire, the respondents also answered statements about performance perception of projects in some indicators of triple constraint. The statements do not directly related the PMO functions to performance, so it was possible to make more assertive and isolated analysis about performance problems of projects in the respondent companies. The indicators to analyze in the triple constraint of the projects were: (X32) - Performance perception in time, (X33) - Performance perception in cost, and (X34) - Performance perception of volume changes in specifications.

The data gathered allowed to calculate the relative frequencies according to the PMO effort to perform functions for supporting higher hierarchical levels, supporting project managers and their teams, and directing projects and /or programs and/or portfolios; and the respondents perception of the level that projects match time, cost or scope performance.

At the end, the analysis simply correlated the answers to the PMO functions with that provide for the perception of project results. More specifically, the aim would be to identify in each PMO the activities with high levels of effort, it means, very high effort (answer " 5 ") or high (answer "4") by the PMO, as those ones less relevant on office operations - very low effort (answer "1") or low (answer "2"). The level of effort " 3 " indicates an intermediate response. The perception of project performance was also answered at five levels. We correlate these answers in form to conclude over which functions can help companies to improve which project success metric.

First of all, only variables of functions were analyzed. The results would be expressed graphically in order to facilitate visualization of the frequency distribution of the data obtained in Likert scale. Figure 1 shows the results of the questionnaire to the functions grouped as "Support to higher hierarchical levels".

These results revealed that in support to higher hierarchical levels, the PMO efforts of the surveyed companies are focused on two functions: "Report project 
status to senior management" (X1) and "Promote project management inside the company" (X8), as visible in Figure 2 that those statements got higher answers in Likert Scale - "high" (4) to "very high" (5). On the other hand, the functions of PMO: "Benefits management" (X4), "Recruitment, selection, evaluation and remuneration determination for PMs" (X5) and "Networking and environmental monitoring" (X6), have low effort in the companies surveyed - most "very low" (1) to "low" (2).

For activities of "supporting project managers and their teams", the distribution in Likert scale is represented graphically in the Figure 3.
For these functions, it can be observed that PMO efforts of the surveyed companies are focused on the three functions which have PMO efforts from "high" to "very high": "Develop and implement a standardized methodology" (X9), "Implement and operate the information system on projects" (X11) and "Develop Project Management skills, including training" (X10). On the other hand, there are four functions with clearly less approach by the surveyed companies from which efforts occur at "low" or "very low" levels: "Implement and manage the lessons learned database" (X14), "Implement and manage the risk database" (X15), "Management of engineering changes"

Frequency distribution of general activities to support higher hierarchical levels

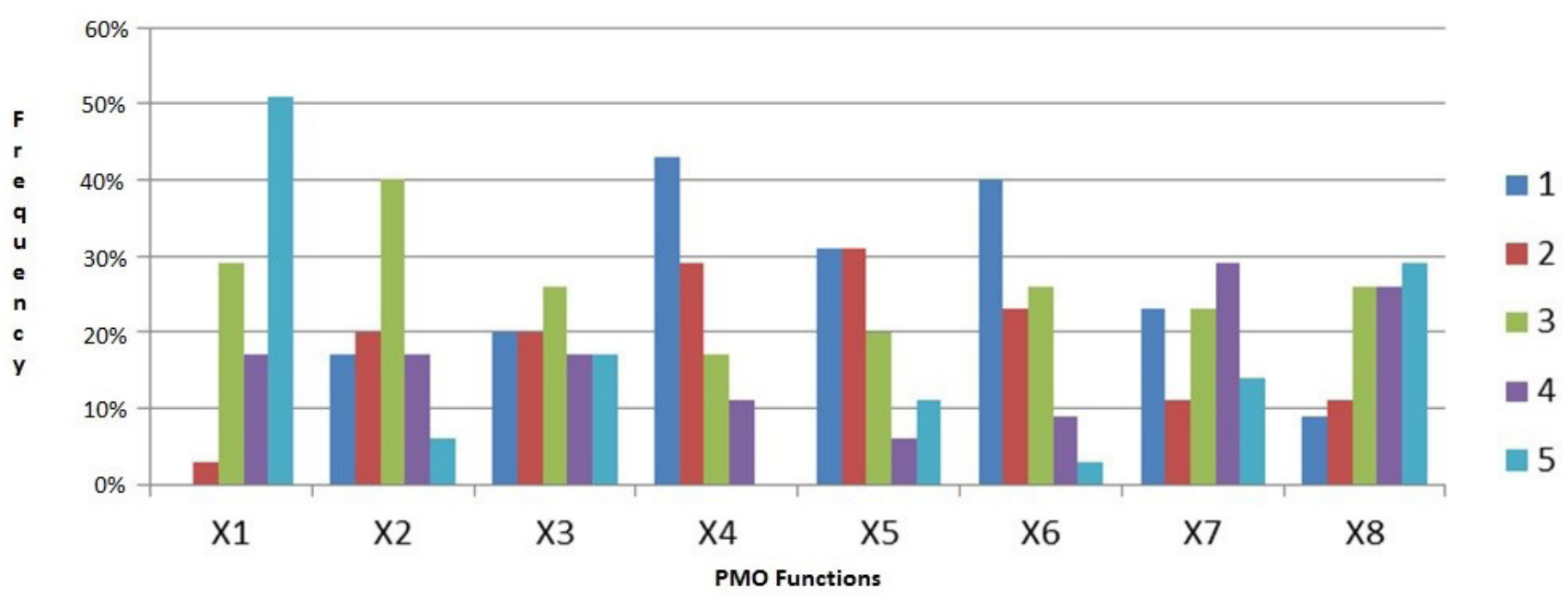

Figure 1. PMOs efforts on functions linked to senior management support.

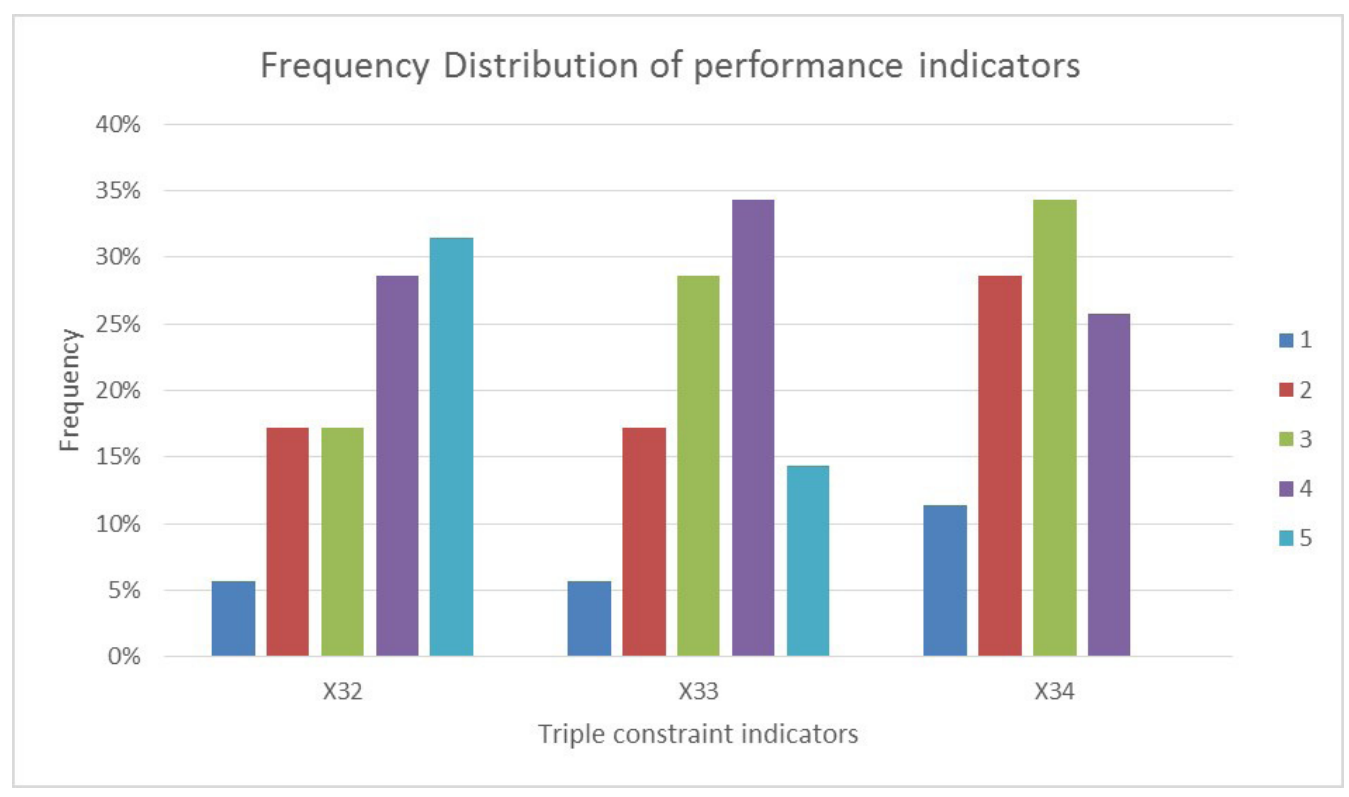

Figure 2. Performance perception of projects in the triple constraint. 
(X17), and "Management of manufacturing items for prototypes/deliveries" (X19) .

Within the functions grouped on "Projects, Programs and Portfolios Management", the function "Manage one or more portfolios" (X25) appears as the activity better internalized by the PMOs under study, as is represented in Figure 3.

Other functions on evidence because of predominant responses of higher PMOs effort according Figure 4 are: "Monitor and control project performance" (X22), "Coordination between projects" (X23), and "Manage files of project documentation" (X27). Besides, PMO's efforts in managing projects, programs and portfolios have tendency for "low" or "very low" in "Set resources allocation among projects" (X30); and "Conduct project audits" (X29).

Summarizing PMOs efforts analysis with the 31 listed functions the highlights of higher efforts are related to provide methodology for project managers and their teams and reporting to senior management. As highlights for PMOs lower efforts are management of benefits and setting remuneration for PM, and the function related to business environment monitoring, all related to the group of senior management support.

The performance of projects in the triple constraint perception from the respondents is represented in Figure 2.

It is explicit the indicator which performance is most affected by PMO is perception in Time (X32), then perception in Costs (X33) and at lastly perception of changes in specifications (X33). This suggests the project analyzed have most good results at deadlines.

The results of performance perception of projects in the triple constraint were combined with the answers for PMO functions. Due to the ordinal nature of the variables associated with the Function and the perception of project performance, the association levels have been checked based on the Spearman correlation coefficient ( $r s$ ). Regarding the Indicators, represented by the variables X32 to X34, there are correlation levels from weak to moderate with variables associated with Function, whose values can be observed in Table 1.

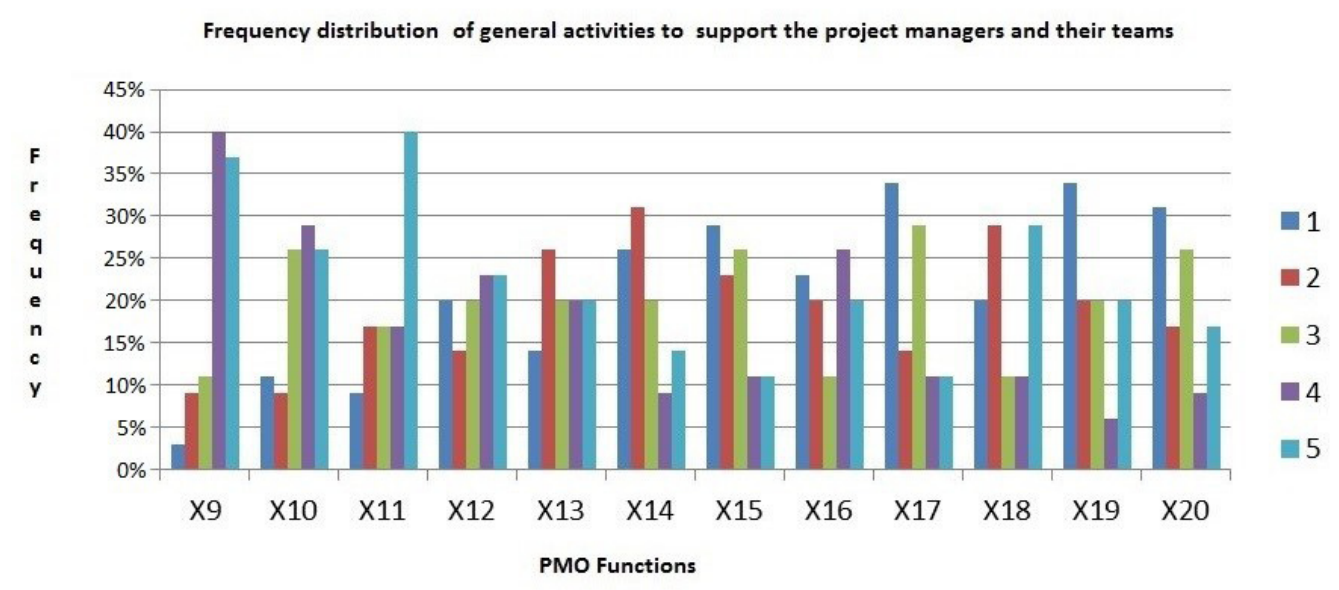

Figure 3. PMOs efforts on functions linked to support the project managers and their teams.

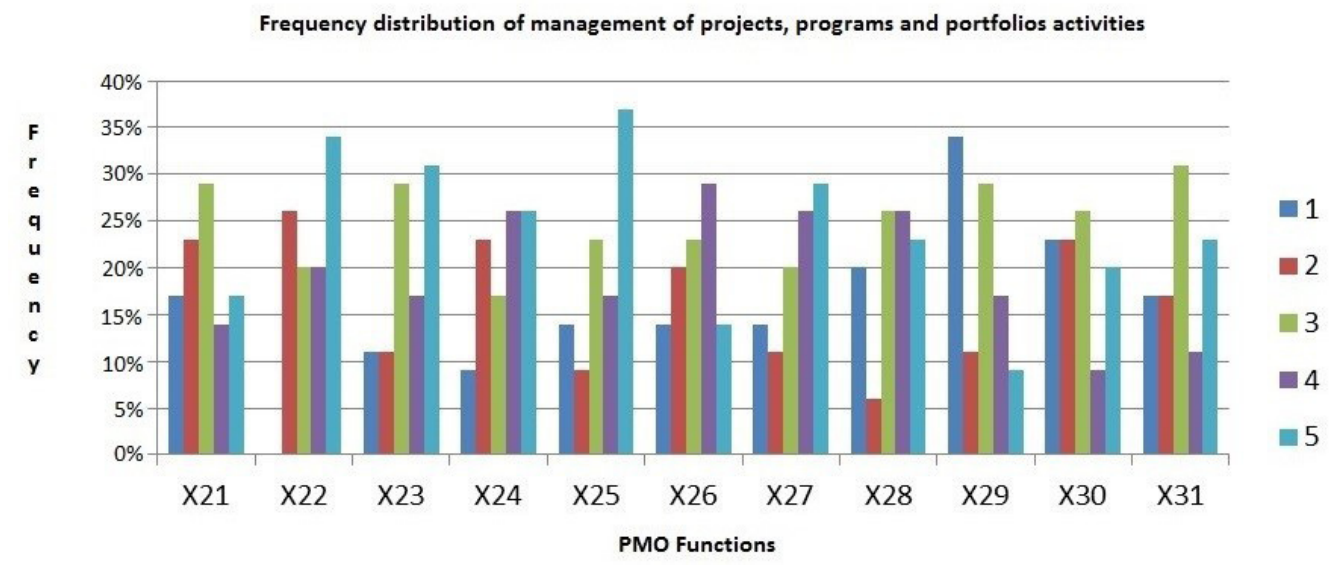

Figure 4. PMOs efforts on functions linked to Projects, Programs and Portfolios Management itself. 
Table 1. Spearman correlation levels for PMO functions correlated to performance of triple constraints.

\begin{tabular}{|c|c|c|c|c|c|}
\hline Indicators & Functions & Variables & rs & P-value & $\begin{array}{l}\text { Correlation } \\
\text { Level }\end{array}$ \\
\hline \multirow{3}{*}{ X32 - Time performance } & $\begin{array}{l}\text { Support to higher hierarchical } \\
\text { levels }\end{array}$ & $\begin{array}{c}\mathrm{X} 1 \text { - Report project status to } \\
\text { senior management }\end{array}$ & 0.39 & 0.022 & \multirow{3}{*}{ Weak } \\
\hline & \multirow{2}{*}{$\begin{array}{l}\text { Management of projects, } \\
\text { programs and portfolios }\end{array}$} & $\begin{array}{l}\text { X27 - Manage files of project } \\
\text { documentation }\end{array}$ & 0.35 & 0.0390 & \\
\hline & & X28 - Manage programs & 0.38 & 0.0230 & \\
\hline \multirow{3}{*}{ X33 - Cost performance } & $\begin{array}{c}\text { Support to higher hierarchical } \\
\text { levels }\end{array}$ & X4 - Benefits management & 0.43 & 0.0090 & Moderate \\
\hline & \multirow{2}{*}{$\begin{array}{c}\text { Support the project managers and } \\
\text { their teams }\end{array}$} & $\begin{array}{l}\text { X14 - Implement and manage } \\
\text { lessons learned database }\end{array}$ & 0.35 & 0.0400 & \multirow{2}{*}{ Weak } \\
\hline & & $\begin{array}{l}\text { X15 - Implement and manage risk } \\
\text { database }\end{array}$ & 0.37 & 0.0300 & \\
\hline X34 - Changes in specification & \multicolumn{5}{|c|}{ No significant correlation with the analyzed functions } \\
\hline
\end{tabular}

There are three functions that are positively correlated with time performance in terms of new products projects. Reporting projects to senior management (X1) can imply indirectly in performance terms by allowing senior management to observe project deadlines and to act for realign them.

The other two functions involved in the results of deadline performance are linked to functions in which there is a direct PMO management on the projects: manage documentation files (X27) and manage programs (X28). Manage documentation files (X27) suggests that document management activities, which work in data organization of the projects and the possibility of data utilization among different projects, implies the non-committing of the same mistakes, and this tends to reduce deadlines. Manage programs (X28) suggests that when projects are grouped and treated as programs whose challenges are coordinated and its management helps to reach common benefits, the result is a better performance in time.

It is interesting to observe that no function in which the PMO acts directly in the project management itself, such as managing manufacture or acquisitions of items (X19 and X20), manage changes (X17) and risk bases (X15) and lessons learned from the project (X14), or even operate the projects information system (X11) and perform specialized activities for managers and their teams (X18), do not imply improvement on project successes in time. As time is a key element in project management, this result suggests that project manager's role, as well as the team, is more closely related to results in time than with functions performed directly by PMOs.

Particularly, literature report cases in which activities X19 and X20 occurred in situations which performance had improved on project lead times (BARBALHO et al., 2014). Here discussed research did not asked respondents if project lead times decreased, but if time performance were realized as good. Maybe another kind of protocol must be used to analyze these issues in a more effective way.
When it is analyzed correlations of the cost performance and functions, data evidenced that the role of the PMO in the implementation and management of databases on risks (X15) and lessons learned (X14) has positive correlation with good performance in costs and this suggests concern to avoid projects past errors. Performance in costs, however, presents an interesting positive, moderate correlation with a performance of the PMO in the management of the benefits offered to project teams (X4). Even seeming obvious, the relationship between acting in benefits management and increasing or reducing project costs was captured by the survey, which reinforces the validity of its results.

For Cost performance it is interesting to note that resources management activities of projects such as "Identify, select and prioritize new projects" (X26), "Set resources allocation among projects" also show no correlation with cost management, and "Recruitment, selection, evaluation and remuneration determination for PMs" (X5) are not related to costs performance achieved by the project. Explain such results is not possible using the research protocol reported here and deserves further studies to identify their causal relationships.

Following the Table 1, it can be seen that none of the functions performed by the PMO has correlation to the volume of changes made in the projects, an indicator that is related with the quality of scope planning. As seen in Figure 2, volume of changes were the indicator which no respondent stated a "very high" (5) score for effort. It maybe have influenced the results of correlation, but in fact no function impacted this scope indicator.

\section{Discussion}

Data presented demonstrates PMO functions can improve project indicators of time and cost. Besides, when analyzing the functions that best correlate the studied indicators, it is observed that no function is correlated with deadline, costs and scope, at the same time, or even with two of these indicators concurrently. This result have 
two sides: it means that a PMO manager has possibility to increase a specific function without decrease the effort on the other, helping to achieve improvements on both - time and cost - indicators. On the other hand, the triple constraint concept has in line with these data, because if a simple function could improve performance of more than one indicator, it would means that PMO functions could have effects on changing the more known trade-off of project management practice: the triple constraint itself.

On the whole, the data related with the indicators of time, cost and volume of changes denotes that the impact of PMO functions on triple constraint of projects is reduced, with few functions that impact in these indicators and no more than a moderate correlation. Data can suggest the hypothesis that these dimensions of project performance would have greater sensitivity to the performance of project managers' activities and/or project teams' activities than to PMO functions. Since these functions tend to work on all the projects characterizing more a portfolio than a project action, and indicators of time, cost and scope would be more tied to specific activities in each project, according to the PMBOK Guide (PROJECT..., 2013).

As PMO tend to work on the aggregation of projects, maybe, it performance could be more precisely measured by indicators related to organizational project management (OPM) as maturity level, team and project management satisfaction or corporate climate (for reference see MARIOKA; CARVALHO, 2014; and PATAH; CARVALHO, 2016), or maybe at a portfolio level as portfolio balance, portfolio value, strategy fitness (COOPER; KLEINSCHMIDT, 1995) or portfolio quality (ÜNGER; GEMÜNDEN; AUBRY, 2012).

In spite of this, important issues are revealed in this stydy: (1) "Which function a PMO can increase if projects are suffering from cost over?" - results point PMO must work on lessons learned, in general or for risk management, and benefits management; (2) "Which function a PMO can focus when scope creeping is occurring frequently?" - in this case, no function can help project managers, according our results; and (3) "Which function a PMO can perform when overtime is common?" - our data suggests that PMO needs to be in touch to senior managers reporting for then the project statuses, and working on managing documents and programs. These kind of questions might help companies to improve their PMO action as a way to contribute for projects' success and not just for its structuration in the company.

In general, performance of projects on time and cost can be benefited by functions which focus is liaison to senior managers (report status), project managers (program management) and human resources (benefits management). They can also be helped by support on documents: from projects (manage files) and from past projects databases (risk and lessons learned).

\section{Final considerations}

This paper analyses results from the data collected in a survey which objective was to characterize the functions performed by project management offices that support the development of new products in industrial companies and analyze these functions from the point of view of some performance indicators used in new products projects. The text presents the most present functions considering performance of project's triple constraints.

The study showed that the indicator chosen to analyze the project scope, volume of scope changes after started the development, has been identified as not related to any function of the PMO. It can be considered that this result indicates that PMO tends to have more income tied to demands of the organization as a whole and not to a particular project. Moreover, scope management is the main issue addressed by project managers, because it denotes the purpose of a project in general. Integration is the capital role of project managers, but this integrative role is directly related to feasibility and viability of delivering the product of the project. So, maybe this result points that scope management are far away from PMO radius of influence than time or cost. This hypothesis can be better analyzed with a distinctive research protocol at the future.

Time and cost performance can be improved by PMO functions, but in different ways. For time, it appears that PMO must act directly on project management activities and report project results to senior management. For cost, the way to success can be support project managers and teams by means of managing and disseminating databases for risk and project knowledge, and at the same time working to human resources to define benefits from projects to people involved on them.

Practitioners can pay attention on the fact that the function of provide project management methodology is one of the most present functions of PMOs researched in this sample, and is not correlate to any indicator of triple constraint. On the other hand, benefits management is one of the functions with less effort on studied PMI, in spite of be moderately correlated to cost performance. Other functions must be well addressed by PMO managers in form to contribute better for project results: manage files of project documentation, manage programs, and the implementation and management of databases for risk and lessons learned.

Future works can also be formatted in order to explore how these discovered correlations act to make this relation to occur effectively. It means, determine the mechanisms by which the functions result in positive outcomes in order to extract best practices on the execution of each one. Moreover, a more expressive sample, eventually international, can be used to explore relations between functions of PMO for NPD and project performance. 
A similar study can be done on PMOs for any kind of project, or maybe in some specific sectors. A specific study can be formatted to understand the impact of PMO on scope management and scope indicators. Finally, studies can be formatted for understanding the impact of PMO functions on other indicators of project success, and even of PMO success in an organizational viewpoint.

\section{References}

AUBRY, M. et al. Project management offices in transition. International Journal of Project Management, v. 28, p. 766-778, 2010.

BARBALHO, S. C. M. et al. Rompendo obstáculos para a implantação de escritório de projetos em empresa de base tecnológica. Gestão \& Produção, v. 16, p. 435-449, 2009.

BARBALHO, S. C. M. et al. Funções dos escritórios de projetos no desenvolvimento de produtos: pesquisa-ação em empresa de alta tecnologia. Production, v. 24, n. 2, p. 322-336, 2014.

BARBALHO, S. C. M.; TOLEDO, J. C. Characterization of profile and main drivers for transitions in project management offices: a longitudinal case study in a hightech company. Gestão \& Produção, v. 21, n. 3, p. 600-620, 2014. http://dx.doi.org/10.1590/0104-530X365

BUSSAB, W. O.; MORETTIN, P. A. Estatística básica. 5th ed. São Paulo: Saraiva, 2003.

CHIESA, V.; FRATTINI, F. Exploring the differences in performance measurement between research and development: evidence from a multiple case study. R \& D Management, v. 37, n. 4, p. 283-301, 2007.

CLARK, K. B.; FUJIMOTO, T. Product development performance: strategy, organization and management in the world auto industry. Boston: Harvard Business School Press, 1991.

CONFORTO, E. C. et al. Can agile project management be adopted by industries other than software development? Project Management Journal, v. 45, p. 21-34, 2014.

COOPER, R.; KLEINSCHMIDT, E. J. Benchmarking the firm's critical success factors in new product development. Journal of Product Innovation Management, v. 12, p. 374-391, 1995.

CRAWFORD, L. The strategic project office: a guide to improving organizational performance. New York: Marcel Dekker, 2002.

DAI, C. X.; WELLS, W. G. An exploration of project management office features and their relationship to project performance. International Journal of Project Management, v. 22, p. 523-532, 2004.
GARCIA, J. G. Análise de la información mercadológica através de la estatística multivariante. Ciudad de Mexico: Alambra Mexicana, 1995. p. 235.

GRIFFIN, A.; PAGE, A. L. PDMA success measurement project: recommended measures for product development success and failure. Journal of Product Innovation Management, v. 13, p. 478-494, 1996.

HEIBERGER, R. M.; HOLLAND, B. Statistical analysis and data display. 1st ed. New York: Springer-Verlag, 2004.

HOBBS, B.; AUBRY, M. A multi-phase research program investigating project management offices (PMOs): the results of phase 1. Project Management Journal, v. 38, n. 1, p. 74-86, 2007.

JORDÃO, R. V. D. et al. Fatores críticos na gestão de projetos: um estudo de caso numa grande empresas latino-americana de classe mundial. Gestão \& Produção, v. 22, p. 280-294, 2015.

JUCÁ JUNIOR, A. S.; CONFORTO, E. C.; AMARAL, D. C. Maturidade em gestão de projetos em pequenas empresas desenvolvedoras de software do Pólo de Alta Tecnologia de São Carlos. Gestão \& Produção, v. 17, n. 1, p. 181194, 2010.

JUGEND, D.; BARBALHO, S. C. M.; SILVA, S. L. Contribuições do escritório de projetos à gestão do portfólio de produtos. Production, v. 26, p. 190-202, 2015.

JUGEND, D.; SILVA, S. L. Práticas de gestão que influenciam o sucesso de novos produtos em empresas de base tecnológica. Produção, v. 20, n. 3, p. 335-346, 2010.

JULIAN, J. How project management office leaders facilitate cross-project learning and continuous improvement. Project Management Journal, v. 39, n. 3, p. 43-58, 2008.

KAHN, K.; BARCZAK, G.; MOSS, R. Perspective: establishing an NPD best practices framework. Journal of Product Innovation Management, v. 23, n. 2, p. 106116, 2006.

MARIOKA, S.; CARVALHO, M. M. Análise de fatores críticos de sucesso de projetos: um estudo de caso no setor varejista. Production, n. 24, n. 1, p. 132-143, 2014.

MENDES, G. H. S.; TOLEDO, J. C. Explorando práticas do desenvolvimento de produtos em pequenas e médias empresas do setor de equipamentos médico-hospitalares. Gestão \& Produção, v. 19, n. 1, p. 103-117, 2012.

PALADINO, A. Investigating the drivers of innovation and new product success: a comparison of strategic orientations. Journal of Product Innovation Management, v. 24, n. 6, p. 534-553, 2007.

PATAH, L. A.; CARVALHO, M. M. Sucesso a partir de investimento em metodologias de gestão de projetos. Production, v. 26, n. 1, p. 129-144, 2016. 
PELlEGRINELli, S.; GARAGNA, L. Towards a conceptualization of PMOs as agents and subjects of change and renewal. International Journal of Project Management, v. 27, n. 7, p. 649-656, 2009.

PROJECT MANAGEMENT INSTITUTE - PMI. Project Management Body of Knowledge: PMBOK. 2013.

RABECHINI JUNIOR, R. et al. A organização da atividade de gerenciamento de projetos: os nexos com competências e estrutura. Gestão \& Produção, v. 18, n. 2, p. 409-424, 2011.

ROBERTS, E. B.; BELOTTI, P. R. Managerial determinants of industrial R\&D performance: an analysis of the global chemicals/materials industry. Technological Forecasting and Social Change, v. 69, n. 2, p. 129-152, 2002.

SILVA, C. E. S. et al. Aplicação do gerenciamento de riscos no processo de desenvolvimento de produtos em empresas de autopeças. Produção, v. 20, n. 2, p. 200-213, 2010.

SILVA, S. L. et al. Critical success factors on product development management in Brazilian technological based companies. In: ISPE INTERNATIONAL CONFERENCE ON CONCURRENT ENGINEERING-RESEARCH AND APPLICATION, 14., 2007, São Paulo, Brazil. p. 739-747, 2007.

SPALEK, S. Improving industrial engineering performance through a successful project management office. Inzinerine
Ekonomika - Engineering Economics, v. 24, n. 2, p. 88-98, 2013.

SPELTA, A. G.; AlBERTIN, A. L. Project Management Offices in the IT Area: A Context-Discriminant Model for their Establishment. Information Systems Management, v. 29, p. 40-54, 2012.

TOLEDO, J. C. et al. Factors influencing new products success in small Brazilian medical and hospital equipment firms. In: ISPE INTERNATIONAL CONFERENCE ON CONCURRENT ENGINEERING-RESEARCH AND APPLICATION, 14., 2007, São Paulo, Brazil. p. 657-664, 2007.

TOLEDO, J. C. et al. Práticas de gestão no desenvolvimento de produtos em empresas de autopeças. Produção, v. 18, p. 2, p. 405-422, 2008.

ULRICH, K. T.; EPPINGER, S. D. Product design and development. New York: McGraw-Hill, 2008.

ÜNGER, B. N.; GEMÜNDEN, H. G.; AUBRY, M. The three roles of a project portfolio management office: Their impact on portfolio management execution and success. International Journal of Project Management, v. 30, p. 608-620, 2012. 